\title{
Microbiota Management for Effective Disease Suppression: A Systematic Comparison between Soil and Mammals Gut
}

\author{
Giuliano Bonanomi ${ }^{1,2, *}$, Mohamed Idbella ${ }^{1,3}$ and Ahmed M. Abd-ElGawad 4,5 (D) \\ 1 Department of Agricultural Sciences, University of Naples Federico II, via Università 100, 80055 Portici, Italy; \\ mohamed.idbella@unina.it \\ 2 Task Force on Microbiome Studies, University of Naples Federico II, 80131 Naples, Italy \\ 3 Laboratory of Biosciences, Faculty of Sciences and Techniques, Hassan II University, \\ Casablanca 28806, Morocco \\ 4 Plant Production Department, College of Food \& Agriculture Sciences, King Saud University, P.O. Box 2460, \\ Riyadh 11451, Saudi Arabia; dgawad84@mans.edu.eg \\ 5 Department of Botany, Faculty of Sciences, Mansoura University, Mansoura 35516, Egypt \\ * Correspondence: giuliano.bonanomi@unina.it
}

Citation: Bonanomi, G.; Idbella, M.; Abd-ElGawad, A.M. Microbiota Management for Effective Disease Suppression: A Systematic Comparison between Soil and Mammals Gut. Sustainability 2021, 13, 7608. https://doi.org/ $10.3390 /$ su13147608

Academic Editor: Ugo De Corato

Received: 4 June 2021

Accepted: 3 July 2021

Published: 7 July 2021

Publisher's Note: MDPI stays neutral with regard to jurisdictional claims in published maps and institutional affiliations.

Copyright: (c) 2021 by the authors. Licensee MDPI, Basel, Switzerland. This article is an open access article distributed under the terms and conditions of the Creative Commons Attribution (CC BY) license (https:// creativecommons.org/licenses/by/ $4.0 /)$.

\begin{abstract}
Both soil and the human gut support vast microbial biodiversity, in which the microbiota plays critical roles in regulating harmful organisms. However, the functional link between microbiota taxonomic compositions and disease suppression has not been explained yet. Here, we provide an overview of pathogen regulation in soil and mammals gut, highlighting the differences and the similarities between the two systems. First, we provide a review of the ecological mechanisms underlying the regulation of soil and pathogens, as well as the link between disease suppression and soil health. Particular emphasis is thus given to clarifying how soil and the gut microbiota are associated with organic amendment and the human diet, respectively. Moreover, we provide several insights into the importance of organic amendment and diet composition in shaping beneficial microbiota as an efficient way to support crop productivity and human health. This review also discusses novel ways to functionally characterize organic amendments and the proper operational combining of such materials with beneficial microbes for stirring suppressive microbiota against pathogens. Furthermore, specific examples are given to describe how agricultural management practices, including the use of antibiotics and fumigants, hinder disease suppression by disrupting microbiota structure, and the potentiality of entire microbiome transplant. We conclude by discussing general strategies to promote soil microbiota biodiversity, the connection with plant yield and health, and their possible integration through a "One Health" framework.
\end{abstract}

Keywords: antibiotics; biochar; compost; diet; soil fumigation; organic amendments; beneficial microbes; soil-borne pathogens; microbiota transplant

\section{Introduction}

Increasing public awareness concerning the sustainability of vegetable and crop production has prompted research into the development of efficient, but low-input, agricultural management practices. Agroecosystems are prone to the spread of pest and plant pathogens, which represent a serious problem for farmers. Intensive cultivation systems based on monoculture are not resistant to biological invasion of pests and pathogens, which can rapidly spread and cause substantial losses to crop production. Standard control strategies include the extensive use of insecticides, fungicides and, in case of soil, disinfestation by the use of fumigants [1]. However, the long-term use of pesticides has environmental and economic negative impacts. At farm scale, the repeated application of pesticides disrupts the soil microbial network, which results in the loss of natural soil suppression, causing greater need for the use of intense applications [2]. At regional and global scale, extensive use of pesticide contributes to environmental pollution [3] and, in recent decades, 
has caused the evolution of weed, insect, and pathogen resistance [4]. With the aim of limiting the environmental impact, the approved list for the safe use of fungicides and fumigants is periodically subjected to revision by European Union, with severe restrictions adopted for many pesticides [5]. However, the progressive restrictions on the use of pesticides increase, in parallel, several risks related to effective crop protection and, in the long term, food security [6]. Therefore, studies that focus on eco-friendly but effective methods for pathogens control are a priority at this time.

The control of soil-borne pathogens by eco-friendly techniques is facing particular challenges due to the capability of these species to survive in the soil for numerous years in an inactive state [7]. For instance, microsclerotia of Verticillium dahliae can survive for more than 15 years without suitable host plants. Several eco-compatible methods have been proposed for use, including disinfestation through solarization [8], bio-fumigation with plant tissue like brassiceous seed meal [9], and anaerobic soil disinfestation consisting of soil incorporation of fermentable organic substrate followed by tarping [10]. An alternative approach that avoids the eradication strategy is the introduction of beneficial microbes or the stimulation of native beneficial microbiota through the use of organic amendment. Organic amendment, like green and animal manure, compost, and biochar, is widely adopted in both conventional and organic farming to increase soil fertility [11], improve soil structure [12], and control the spread of soil-borne pathogens [13]. The list of pathogens approved to be controlled by organic amendments includes bacteria (e.g., Ralstonia solanaceaurum), oomycetes (e.g., Pythium spp., Phytophthora spp.), many fungi (e.g., several Fusarium oxysporum forme specialis, Rhizoctonia solani, Sclerotinia minor, Sclerotium rolfssi, and Verticillium dahliae) and some viruses [14]. Within the literature, four main mechanisms have been proposed to explain the capability of organic amendments to control soil-borne pathogens: (i) increased competition for nutrients that causes fungistasis [15], (ii) antibiosis and hyper-parasitism [16], (iii) induced systemic resistance by beneficial microbes (Zhang et al. 1998), and (iv) direct fungitoxic effect of organic compounds released during the decomposition of the organic substrate [17]. Despite the underlying mechanisms that have been clarified in several previous study cases, their relative importance and impact under field conditions is still poorly understood. Therefore, the extensive commercial application of organic amendments is still limited by the lack of predictability and consistency of the achievable results in different plant-pathogen systems. In fact, several studies have found that organic amendments are not effective in disease control and, in some cases, may incite plant disease incidence and severity [18]. Indeed, an improvement of the mechanisms that regulate organic amendment-based disease suppression will help to develop new and more effective product applications. In recent decades, several reviews have explored the connection between organic amendment and disease suppression, trying to quantify their effectiveness, the underlying mechanisms, and the efficiency of the application of specific materials like compost "tea" [19] and biochar [20]. More recently, the connection between soil microbiome and organic amendment application under different farming systems has been also reviewed [21,22].

In the last ten years, the key role of microbiota for soil and plant health has become a central topic for research activities [23]; and agronomic practices, including pesticides and organic amendment, are strong factors affecting the structure and functionality of these microbiota [24]. In this review, we explore the opportunity provided by recent advances of chemical and metagenomic tools in the studies that link organic carbon sources with both microbiota composition and functions to pathogen spread and invasion in soil and animal gut. In this context, we explicitly compare the role of the gut, where the role of the microbiota in a mammal's health is well established, and soil microbiota in controlling pathogens. Specifically, our effort is devoted to identifying common and divergent points with the aim of improving organic amendment applications. We start by investigating how microbiota responds to repeated disturbance practices, i.e., fumigants in agricultural soil and antibiotics for mammal gut. Then, we investigate the potential mode of stirring suppressive microbiota by comparing organic amendment application in soil and diet 
regimes for human. Finally, we discuss the potentialities as well as the limitations of microbiome transplant in the soil of agroecosystems and mammals gut.

\section{Antibiotics, Fumigations, Microbiota Disruption and Disease Reappraisal}

Since the discovery of antibiotics in 1940, they have been a keystone innovation in several fields including medicine, public health, and animal husbandry. It is well established that the use of antibiotics carries both risks and benefits. Therapies based on antibiotics are critical for the effective cure of life-threatening infections of humans and animals, but extensive use could lead to side effects that include emergence and spread of antibiotic resistance [25]. At an individual scale, the use of antibiotics may cause shortterm collateral damage by impairing the indigenous host-associated microbiota. In detail, broad-spectrum antibiotics cause rapid but transient reduction of bacterial diversity in the gut, associated with the collapse of some specific bacterial taxa. As a consequence of microbiome diversity decrease and formation of empty ecological niches, the resistance to biological invasion by pathogenic species decreases drastically [26].

The importance of an intact intestinal microbiota for mucosal protection from pathogen infection has been widely demonstrated for both animals and humans. First, the use of germ-free animals has clearly demonstrated that such model organisms are extremely susceptible to enteric infection [27]. Second, several studies have reported that the application of broad-spectrum antibiotics could increase the susceptibility to pathogens attacks by many species including Escherichia coli, Salmonella enterica, and Vibrio cholerae [25,28,29]. The loss of colonization resistance to pathogens invasion could be within a short-term period, as in the case of Salmonella infection often observed in the days that follow antibiotic applications [26]. Direct competition for organic compounds as well as interference competition are involved in the short-term resistance to colonization by pathogens provided by the intact microbiota. Antibiotics cause a rapid reduction of the inner microbial population, a drop in microbiome diversity, and the disruption of the community structure. A study using a mouse model indicated that antibiotics could lead to an episodic, local increase in the abundance of host-derived organic compounds in the gut, including free sugars and sialic acid, which triggers their use by pathogens like Clostridium difficile and Salmonella enterica [30].

In general, the impact of antibiotics on gut microbiome composition is represented by a sharp reduction in bacterial diversity, with more or less complete recovery some weeks after the treatment. Moreover, steep declines and expansions were observed in the relative abundances of specific bacterial taxa. In most taxa, a nearly complete recovery was observed several weeks after the treatment, although some long-lasting effects after several months were reported [31]. The long-term legacy effect on specific microbial taxa could be associated with the persistent reduction of colonization resistance. For example, Croswell et al. [26] found that different antibiotic regimens perturbed the mice's gut microbiota, enhancing Salmonella enterica colonization immediately after the treatment. However, despite the rapid microbiota recovery in terms of bacterial counts and the relative abundance of several dominant taxa, the mice retained their susceptibility to Salmonella spread and associated enteritis. This result demonstrated the long-lasting deleterious impacts even after withdrawal of antibiotics treatment. Similar findings have been reported in the case of Clostridium difficile-associated diarrhea infection, in which the therapies are commonly based on antibiotics that are $70-85 \%$ effective against initial episode patients, but these values dramatically drop to $30 \%$ in the case of patients with subsequent disease relapses [32]. In fact, subjects prone to disease relapse have a microbiota depleted of specific taxa because of the repeated antibiotic treatments that make the whole microbiota less resistant to recolonization by the germ $C$. difficile [33].

In the agroecosystem, the use of antibiotics is banned in the European Union, although field application is still possible in the USA and some other countries. Nonetheless, agricultural soils under intensive management are often subject to reiterated and intensive applications of pesticides, in particular fumigants. Fumigants are usually applied as a pre- 
plant treatment for vegetables, or in the case of replanting in orchards. Fumigants, usually having a broad spectrum of activity, are applied to eradicate pathogenic bacteria, oomycetes, fungi, nematodes and also weeds. The global ban of methyl bromide in 2005, due to the depleting effect on stratospheric ozone, caused the substitution with other products like chloropicrin, metam sodium, and 1,3-dichloropropene, among others [1]. However, despite the extensive use of fumigants in many agricultural systems, soil-borne pathogens are still causing considerable crop losses. In this regard, recent studies suggest that fumigants contribute to the development of soil microbiota that are subject to disease relapses due to their loss of resistance to pathogens colonization. In the short term, fumigation causes a notable reduction of pathogens inoculum, a drop of bacterial and fungal diversity, and subsequent release of mineral nitrogen forms by mineralization of killed microbial biomass. Reduction of pathogen density and the release of mineral nutrients contributes to the well-known stimulation of plant growth immediately after soil fumigation [34,35], and contributes to their extensive application in different agricultural systems. However, the short-term vegetation lush has considerable environmental costs, including the decline of soil organic carbon stock [36] and the reduction of soil suppressiveness against pathogens. As reported for gut microbiota treated with antibiotics, fumigated soil often shows a rapid recovery of microbial biomass, as well as diversity that often reaches the pre-existing state, or even higher levels, a few weeks after the treatment $[37,38]$. This pattern has been reported for a range of fumigants. However, most of the available studies are short term and were reported to be transient, but significant changes have been in the taxonomic composition of fumigated soil compared to untreated control $[39,40]$. Nevertheless, studies monitoring microbiota response over multiple years in fumigated soil were lacking until recent years, resulting in the inability to assess the long-term effect of this practice on microbiota resistance to pathogen infestation, crop health and yield. A notable exception is the study of Mazzola et al. [9] concerning the effect of 1,3-dichloropropene-chloropicrin in overcoming the replant disease problem of apple (Malusdomestica) caused by the nematode Pratylenhcus penetrans, the fungus Rhizoctonia solani, and the oomycetes Pythium. The positive effect of fumigation on tree growth was limited to the first season but disappeared thereafter. In the first year, soil fumigation reduced nematode and pathogen abundance in the rhizosphere microbiota of apple trees. However, after two years, the microbiome in the untreated control and fumigated soil was not different, with substantial nematode lesion and pathogen attack in root planted in fumigated soil, demonstrating the limited resistance of this soil to pathogen re-establishment. More recently, Bonanomi et al. [41] investigated the impact of organic amendment application and chemical fumigation with metam sodium for two years on the crop yield of rocket (Eruca sativa) and the soil microbiota structure. Fumigated soil achieved the highest yield in the first year, but the lowest after two seasons due to soil acidification, increased soil salinity, and sharp reduction of soil microbiota activity and diversity. More generally, Bonanomi et al. [42] compared the soil microbiota of greenhouse vegetable cultivation managed organically or conventionally based on mineral fertilizer and repeated soil fumigation. Notably, anellida belonging to the family Enchytraeidae, were practically absent under conventional management, but were a very abundant component of the soil microbiome in organic farms. This demonstrates that repeated fumigation disrupts the upper levels of the soil microbiome food web, with a negative impact on ecosystem functions. Accordingly, we found that the organic soils were more suppressive to the spread of the fungal pathogen $R$. solani compared to conventionally managed soils [43].

This section highlights that the application of broad-spectrum biocides on species' rich, complex microbiota, like that harbored by mammals' guts and soils, causes short-term negative effects as well as long-lasting legacy impacts (Figure 1). In both guts and soils, antibiotics and fumigation perturb microbiota equilibrium, enhancing the susceptibility to pathogen re-establishment. Accordingly, with the fluctuating resources hypothesis [44], ecosystems subject to periodical disturbance become prone to biological invasion because their capability to efficiently use available resources is drastically reduced. In this regard, the use of aggregate microbiota traits like microbial biomass, total cultivable bacteria, 
species richness and diversity are all unable to predict the long-lasting negative impact of biocides. Further studies that identify synthetic microbiota traits able to capture the shortand long-term impact of biocide treatments are urgently needed.

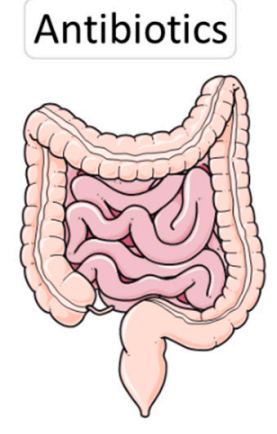

- Short-term diversity reduction

- Simplification of microbiota network

- Disease reappraisal

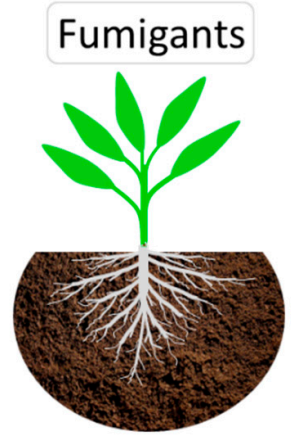

- Short-term diversity reduction

- Disruption of soil food-web structure

- Loss of natural disease suppression

Figure 1. Application of broad-spectrum biocides, i.e., antibiotics in gut and fumigants in soil, causes short-term reduction of microbiota diversity but also long-lasting legacy effects by enhancing susceptibility to pathogen re-establishment, caused by the reduced capability of available resources efficient use.

\section{Microbiome Stirring to Enhance Disease Suppression}

Soil and the gut are considered to be bioreactors in which very complex microbiota, potentially made up of trillions of living cells dominated by bacteria in the human gut and hundreds of bacterial and fungal species in soil, coexist by competing and exploiting a range of organic carbon sources. Temperature, available oxygen, and $\mathrm{pH}$ are the main abiotic factors that shape soil and mammal gut microbiota, with both the content and chemical quality of the exogenous organic carbon that provides the fuel supporting its activity and, through intense competition, shapes community diversity and taxonomic composition [45]. Organic carbon input in the soil of natural ecosystems consists of freshly fallen litter, root exudation, and turnover, and, in agroecosystems, exogenous application of organic amendments makes a further contribution [46]. In humans and mammals, diet is the primary source of organic carbon for the gut microbiota, which supports the animal's energy requirement. In both gut and soil, the microbiota can be altered by external stimuli, and its plasticity creates opportunities to reshape diversity and structure. As demonstrated in animals and humans, where gut microbiota diversity and composition can be reshaped by the diet [47], the content and chemical quality of crop residues and organic amendment are crucial for stirring soil microbiota. In this context, an accurate definition of diet and organic amendment chemical composition is a crucial step to developing reliable guidelines for the correct and effective management of microbiota by modulating diet and organic amendment type, and the amount and frequency of application.

\subsection{Gut Microbiota, Diet and Human Health}

Diet plays a pivotal role in human health, with unbalanced food intake being linked to chronic [48] and cardiovascular diseases [49]. Diet not only provides essential nutrients and carbon sources to support human metabolism, but also feeds gut microbiota that modulates human physiology, psychology, and, finally, health [50]. Several studies have extensively reviewed the intersection between different dietary patterns (e.g., Mediterranean diet, Western diet, ketogenic diet, Paleolithic diet, and vegan/vegetarian diet, among others), gut microbiota, and human health $[51,52]$. In recent decades, scientists have recognized that both macro- and micro-nutrients affect the gut microbiota, but among macronutrients, carbohydrates $(\mathrm{CHO})$ play a principal role [53]. The Western diet, which is rich in fat 
and simple $\mathrm{CHO}$, mainly sucrose, causes a rapid shift in the microbiota and could trigger metabolic dysfunction in model animals [54]. Similar deleterious effects have been reported with high sucrose dosage when applied in other dietary patterns. Conversely, dietary patterns rich in fiber and indigestible $\mathrm{CHO}$ can remodel microbiota with positive consequences for human health. Accordingly, diets rich in fibers and poor in simple $\mathrm{CHO}$, like those employed by the societies of nomadic hunter-gatherer populations, supports a very rich gut microbiota. Such species-rich gut microbiotas are able to enzymatically degrade several $\mathrm{CHO}$ that are indigestible to humans, thus providing a slow energy release. Some authors have proposed the term "microbiota-accessible carbohydrates" (MAC) instead of the generic term "fiber" to better identify $\mathrm{CHO}$ that are accessible to gut microbiota [55].

There is evidence to suggest that diet patterns deprived of MAC alter microbiota structure, diversity and functionality. In animal models, diets with low levels of MAC cause a rapid decrease in microbiota diversity that persists for several generations even after the reintroduction of an appropriate diet [55]. Similarly, lower diversity of gut microbiota is observed in Western societies that follow a diet poor in MACs but rich in fat and simple sugars. Notably, this lower diversity was associated with over-grazing by some bacterial taxa in search of alternative carbon sources on the intestinal mucus layer. Depletion of the mucus layer causes inflammation and opens the way to pathogen attack [56,57]. Moreover, MACs provide key carbon sources for gut bacteria that produce, through fermentation, several short-chain fatty acids, including butyrate and propionate. Short-chain fatty acids in the intestine are important compounds that regulate energy homeostasis, as well as lipid and $\mathrm{CHO}$ metabolisms, and suppress inflammatory responses [58]. In this regard, restriction of MACs in the diet can substantially reduce short-chain fatty acid production, thus impairing several physiological processes (Figure 2). To overcome the chronic deprivation of MACs caused by the Western diet, some oligosaccharide MACs have been proposed as diet prebiotics to selectively stimulate the proliferation of beneficial species like Bifidobacterium and Lactobacillus. Despite promising experimental data, results in this direct are contradictory [59]. More generally, the available evidence indicates that a delicate balance between intake of simple $\mathrm{CHO}$ and MACs is required to support diverse and functional gut microbiota. In this context, some researchers are focusing their attention on the definition of microbiota-targeted dietary patterns, like the specific carbohydrate $\operatorname{diet}[60]$.

\subsection{Organic Amendment to Feed Soil Microbiota and Promote Disease Suppression}

The amount and chemical quality of organic input in the soil ecosystem shapes the microbiota and, in return, controls soil function, including fungistasis and disease suppression. In natural ecosystems, litterfall, root exudation, and microbial turnover are the main organic input in soil, more or less continuously feeding a complex food-web largely composed of microbial saprotrophs and invertebrate detritivores [61]. It is well known that leaf and root litter chemistry varies dramatically among plant species in relation to the plant type (e.g., broadleaf, conifer, nitrogen-fixing, sedge and grasses), and within species in terms of the organs (e.g., leaves, root, and wood debris). The leaf economic spectrum predicts that leaf litter chemistry changes with soil fertility, with litter tissue being richer in nitrogen and poor of structural lignin as fertility increases [62]. Moreover, plant leaves have a higher nitrogen content and a lower lignin content compared to root and woody tissues [63]. Overall, the organic input received by a certain ecosystem depends on the biochemical composition of plant tissues type, the frequency of litterfall, the intensity of turnover, and the type of abiotic stress, including fire, which provides, in addition to inorganic ash, also charred materials with specific chemical and functional properties [64].

In agroecosystems, organic amendments, like manure, have been used for millennia to support soil fertility and functional microbiota. In the last century, instead, the introduction of synthetic inorganic fertilizers has allowed farmers to break the link between organic amendments that feed microbiota and soil fertility and crop yield [13]. As a result, organic materials present in agroecosystems, including crop residues and manure from key 
resources, have become solid waste. In most ecosystems, crop residues are removed from soil or burned to reduce pathogen inoculum and limit the spread of plant diseases [65]. Moreover, in well-watered and fertilized agroecosystems, the litter quality is higher, i.e., it possesses high $\mathrm{N}$ and labile carbon content with low lignin concentration, thus supporting a high decomposition rate and fast carbon cycle. As a consequence, the microbiome can become starved and receive only periodic input of organic matter, mostly composed of very labile carbon forms like sugars and amino acids from root exudates, and highly decomposable crop residues. It is well established that reductions in organic input cause reductions in soil organic carbon stock, as well as a progressive reduction of nutrient mineralization [36]. Less known, however, are the associated changes in the microbiota, which becomes dominated by fast-growing, opportunistic bacteria, in particular Proteobacteria, but depleted of oligotrophic Acidobacteria. More importantly, several studies have observed a reduction in fungal biomass and functionality, especially the guild of saprotrophic species capable of decomposing plant debris rich in lignin, associated with the reduction of the organic inputs $[66,67]$. Under such conditions, microbiota are less capable of using the periodical input or organic matter, opening up the possibility for the spread of pathogenic fungi capable of saprotrophic activity, like Rhizoctonia solani, Fusarium species, and Pythium spp. Such changes have important feedback effects on crop yield and health. Soil sterilization, through heat and steam, has become routine in nursery and intensity cultivation, as well as fumigation under field conditions. The popularity of this practice derives from farmers' requirement to periodically remove dysbiotics, pathogen-rich microbiota, from soil. In support of this practice, most of the studies that have compared non-sterile with sterile soil collected in intensively cultivated agroecosystems found a notable increase in plant growth following microbiota removal [68-70]. Conversely, in semi-natural grasslands and forest soils, sterilization, in most cases, causes a reduction in plant growth, indicating the associated positive soil microbial community feedback [71,72]. We speculate that periodical sterilization combined with reduced carbon input in agroecosystems causes a systematic removal of highly specialized microbes like ectomycorrhizal fungi, saprotroph fungi capable of degrading lignin, predator protozoa, and metazoan, thus causing a disruption of food web upper levels [42]. Unfortunately, most such microbes have low resilience, and as a result, become locally extinct, and the limit dispersal capability does not allow their rapid soil recolonization.

Restoration of dysbiotic soil microbiota could be pursued by managing the frequency of application and the chemical quality of organic amendment. Usually, in order to adapt the application of organic amendment to ordinary agricultural practices, organic inputs are applied once a year and in large amounts, often exceeding 20-30 tons per ha per year [18]. Although this is practically simple, the consequence is the generation of alternating bursts and declines in microbial activity, causing fluctuations and general instability in the functionality of the soil microbiota, which becomes prone to pathogen invasion $[73,74]$. Notably, the few experiments that have studied the use of organics amended frequently (i.e., applied every week or month) and at low rate reported a positive response of soil microbiota, with higher enzymatic activities [75] and total active microbial biomass [76]. Bonanomi et al. [77] found that frequent applications (i.e., every two days) of four organic amendment types were able to increase soil fungistasis against four pathogenic fungi, i.e., Aspergillus niger, Botrytis cinerea, and Pyrenochaeta lycopersici. Specifically, soil subjected to repeated organic applications required a substantially reduced time for the restoration of fungistasis, and hence, there was a reduced window of opportunity for pathogens to use the organic source, and increasing the potential inoculum. In general, a frequent rate of organic amendment provides continuous support to soil microbiota, but more studies are required to adapt this principle to different cultivation systems.

The other option for stirring suppressive soil microbiota is to use the appropriate organic amendment type. In this regard, the trial and error approach has been applied for a long time, although with little benefit. According to the meta-analysis of Bonanomi et al. [18], based on 2423 experiments, organic amendment had a suppressive effect in $45 \%$, and a non- 
significant impact in 35\% of cases, but there was a notable increase in disease severity in $20 \%$ of the bioassays. In this context, the key question is how to profit from organic amendment with the aim of reshaping the soil microbiota and enhancing the activity of beneficial microbes without stimulating pathogen populations and virulence. In fact, the identification of the appropriate organic amendment type for shaping the suppressive microbiota is a crucial, but not easy, task. As observed for the human gut, agroecosystems, where easily accessible carbon sources are the main organic input, sustain dysbiotic microbiota and are subjected to pathogen spread. In this regard, the use of materials rich in recalcitrant organic carbon, like sawdust rich in cellulose and lignin, seems a profitable approach. Cellulose and lignin-rich materials stimulate saprotrophic fungi, which increase the competitive ability of soil microbiota against pathogens including R. solani [78]. However, this practice is limited because of its obligation to be combined with large applications of mineral fertilizers in order to avoid nitrogen immobilization in the microbial biomass due to the high $\mathrm{C} / \mathrm{N}$ ratio of such organic materials [79]. The use of biochar, a pyrogenic material that is highly recalcitrant to microbial attack, appears also to be a profitable approach against a range of plant pathogens. In the past decade, biochar has been found to be able to suppress diseases caused by both soil-borne and airborne fungal pathogens, including B. cinerea, Leveillula taurica, and several formae speciales of F. oxysporum, Pythium spp., Phytophthora species and $R$. solani [20]. Recently, biochar was shown to be able to control the parasitic weed Phelipanche aegyptiaca [80], the nematode Pratylenchus penetrans [81], and the Tomato Spotted Wilt Virus [14]. The mechanisms of disease suppression of biochar are related to its high specific surface area and the recalcitrant carbon type. During pyrolysis, the disappearance of easily degradable carbon sources, the enrichment of aromatic fractions and the increase of specific surface area make biochar an organic substrate capable of stimulating plant growth, but not capable of acting as a food base for microbes, especially pathogens with a limited saprophytic ability. Moreover, due to its porous structure, biochar provides a safe site for beneficial microbial colonies [82], and adsorbs phytotoxic molecules and enzymes used by pathogens to attack plants [83]. One promising approach is the combination of biochar with other, non-pyrolyzed, organic amendments like manure, plant residues and compost. Such products are commercially termed "terra preta"-like planting substrates [84]. In fact, specific combinations of biochar made from four feedstocks, i.e., the organic fraction of municipal waste, Medicago sativa, Zea mays stalks, and wood chips, with non-pyrogenic substrates have been found to be very effective in stimulating plant growth [85], thanks to their capacity to adsorb potential phytotoxic compounds and, at the same time, progressively release mineral nitrogen [86]. Overall, the use of slow-decomposing substrates (i.e., cellulose and lignin-rich material or pyrogenic substrates like biochar) that avoid the boom-down response and the fluctuation of soil microbiota require special attention in future research targeting the development of suppressive soil (Figure 2).
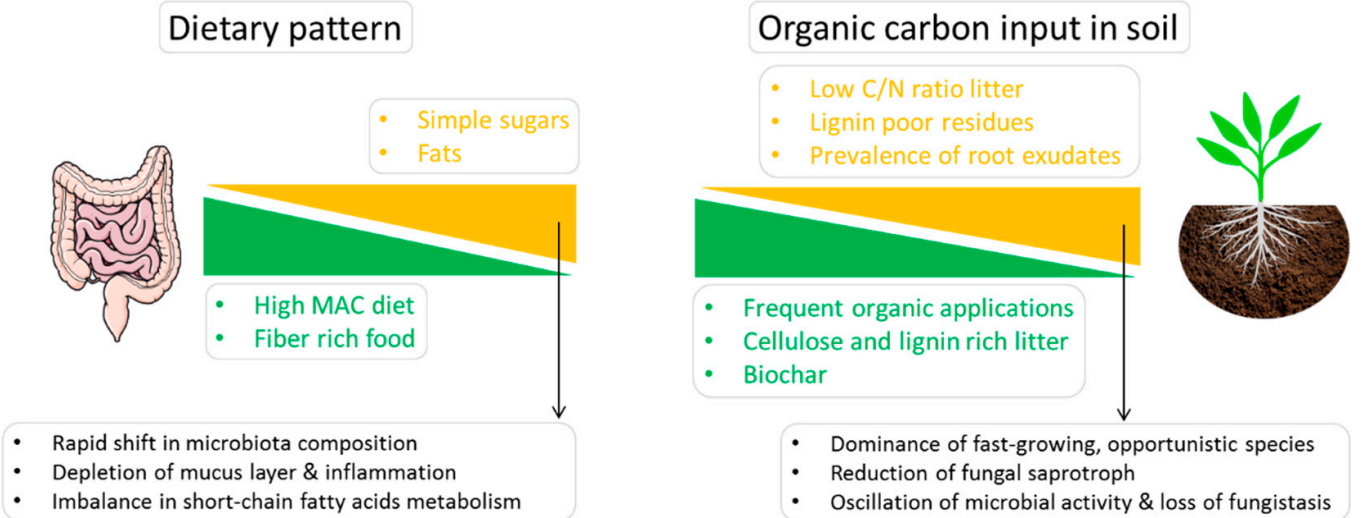

Figure 2. Soil and gut harbor complex microbiota sustained by organic carbon inputs. Dietary pattern in gut and the assembly of freshly fallen litter, root exudation, microbial turnover and exogenous organic amendments in soil shape 
microbiota structure and control functions. In both systems, the prevalence of simple, easily accessible organic carbon sources induces instability and generates dysbiotic microbiota.

\section{Microbiome Transplant: Potentialities and Drawbacks}

Reconstruction of a depleted microbiome can be performed through the introduction of beneficial microbes. A major achievement in plant disease protection was the isolation, development, and commercialization of beneficial microbial inoculants in different agricultural systems. Such probiotics commonly include well-known beneficial bacteria, e.g., Bacillus, Pseudomonas, and Streptomyces, or fungi, e.g., Trichoderma, Coniothyrium, and non-pathogenic Fusarium strains, among many others. The usefulness of probiotics in agriculture is proven by the number of commercial products sold on the market worldwide [87]. However, many such beneficial microbes are very effective under laboratory and greenhouse conditions, but often fail in field applications. Several studies have suggested that single-species probiotics suffer intense competition from native microbiota and, in many cases, are poorly adapted to the ecological conditions of the donor soil ecosystem [88]. As a consequence, the effectiveness of such microbes requires an inundation approach based on periodic application of large amounts of living bacterial cells or fungal spores, with obvious increased costs for farmers. Similar problems have been reported for the use of probiotics, based on single strain of Bifidobacterium and Lactobacillus, for the restoration of depleted gut microbiota [59]. A possible solution to this problem is the combination of biocontrol agents belonging to different functional types in order to reduce the biological control variability. Such microbial consortia are often composed of antagonistic fungi, mycorrhizal fungi, and plant growth-promoting rhizobacteria [89]. However, the major drawback of microbial consortia is the limited species richness, usually less than 10 strains, and the lack of specific adaptation to the donor ecosystem, which limits their capability to effectively establish and colonize the new environment. A further step in this direction would be the inoculation of the entire microbiome, which is much more complex, and is composed of hundreds or even thousands of species. Hereafter, we compare studies concerning microbiome transplantation in three systems: gut, vagina, and soil. Although the methods are technically different in terms of practical aspects and implementation, the approach and the logical bases are identical. The following sections highlight the similarities and differences with a focus on pathogen resistance.

\subsection{Microbiota Transplant in Gut and Vagina}

The entire microbiota transplantation in human consists of the transplantation of fecal microbiota from a donor, healthy individual, into an individual suffering from gastrointestinal disorders with the aim of restoring the normal functionality of the recipient's gut. The history of fecal microbiota transplant dates back to the 4th century in China, where it was used as a therapeutic tool to treat diarrhea in humans [90]. However, the delivery of dry feces or fresh fecal suspension by mouth to patients limits the diffusion of this technique for obvious reasons. In animals, in the 17th century, the fecal transplant was termed 'transfaunation' and was used in ruminants to restore microbiota in order to improve the digestion process or different metabolic disorders [91]. Recent applications of microbiota transfer have also been successful in other mammals as well as fish [92].

In modern medicine, Eiseman et al. [93] firstly published case studies concerning fecal microbiota transplant as a successful method for the treatment of enterocolitis associated with infection of Staphylococcus aureus. In recent decades, fecal microbiota transplant has entered hospitals and clinics as a successful tool option for the treatment of diarrhea caused by Clostridium difficile infection [32]. In fact, fecal microbiota transplant treatment has been demonstrated in clinical trials to be effective in the treatment of recurrent $C$. difficile infection in about $90 \%$ of cases, without reporting any severe adverse effects. For instance, Fuentes et al. [33] reported that after fecal microbiota transplant, all patients successfully recovered from recurrent $C$. difficile infection. Moreover, microbiota composition shifted from low diversity dominated by Proteobacteria and Bacilli, typical of post-antibiotic 
treatment, to a more species-rich microbiota dominated by Bacteroidetes and Firmicutes groups, with changes that were persistent over time. Recent research efforts have been devoted to optimizing delivery systems, as well as the identification of the donor microbiota traits necessary to provide effective and safe pathogen-free samples [94]. Fecal microbiota transplant had a positive effect, although results are more variable, and in some cases controversial, for the treatment of inflammatory bowel disease [95], Crohn's disease [96], ulcerative colitis [97], functional gastrointestinal disorders [98], obesity [99], and insulin sensitivity in patients with other metabolic syndromes [100]. For this majority of diseases, the mechanism underlying the fecal microbiota transplant effect is still unknown, but a net increase in the abundance of beneficial bacteria combined with the increase in the microbial diversity is likely, as is the indirect modulation of the immune system [101]. Fecal microbiota transplant is the current object of several studies in veterinary science with applications in improving the health of wild, endangered species in zoos [102] and domestic pets [103], and improving efficiency in livestock husbandry [104].

More recently, microbiome transplantation has been used for the treatment of intractable bacterial vaginosis. Contrary to the complex microbiota of the gut or soil, where microbial bacterial diversity is an indicator of healthy ecosystems, the healthy microbiota of the vagina is dominated by only one of a few species belonging to the Lactobacillus genus [105]. In these systems, an increase in bacterial diversity is a symptom of disorder. Specifically, bacterial vaginosis consists of an alteration of the vaginal microbiota that switches from Lactobacillus monodominance to the presence of different anaerobic species [106]. Bacterial vaginosis increases the risk of infections in the upper genital tract, complications in pregnancy, and enhances susceptibility to sexually transmitted diseases [107]. Bacterial vaginosis is commonly treated with antibiotics, but such intervention is associated with a substantial relapse of up to $50-70 \%$ within a year [108]. Repeated antibiotics application, as described for soil and gut, opens the way to vaginal candidiasis, and infection by resistant bacterial strains. The use of probiotics consisting of Lactobacillus strains, either applied orally and/or in the vagina, has produced very variable results and was unable to restore a stable and healthy microbiota [109]. In recent years, some studies have demonstrated that transplants of vaginal fluids from selected healthy donors could be an effective approach for the restoration of functional microbiota $[105,110]$. The most recent studies developed standard protocols to ensure that only beneficial microbes are transferred, avoiding the presence of potential pathogens, but also sperm that could cause unintended pregnancy. Moreover, future studies will focus on the effective screening of donors that are not only pathogen free, but harbor a Lactobacillus-dominated microbiota that can effectively restore the vagina of the recipient. Future studies should address the idea of cultivating uniform, more standardized transplants that have high therapeutic efficacy while limiting the risks associated with the use of vaginal fluids.

\subsection{Microbiota Transplant in Soil Ecosystems}

In many agricultural systems, soils are periodically sterilized by the use of physical factors like steaming, but, more commonly, they are sterilized through chemical fumigation. This agronomic practice, by removing the pre-existing microbiota, creates favorable conditions for hosting exogenous microbiota because of the reduced competition by the native microbial community. Therefore, such agroecosystems appear to be ideal systems for the effective transplantation of entire functional microbiomes. Early evidence of soil transplantation date back to the 1930s and 1940s, with studies concerning suppressive soils. The transferability of disease suppression was elegantly demonstrated by the addition of small amounts of suppressive soil, ranging from less than $1 \%$ to $10 \%(w / w)$, to a disease-conducive soil which rapidly leads, as a consequence, to the transfer of the capability to control the disease [111]. The use of a small amount of soil rules out the possibility that changes in soil chemistry (e.g., pH, organic carbon, nitrogen, etc.) could be the causes of disease suppression. One of the earliest documented transfers of suppressive microbiota was published by Menzies [112]. In this study, a small amount of transferred living, conducive, sterilized soil 
resulted in a dramatic reduction in potato scab caused by Streptomyces scabies. Notably, more recent studies have demonstrated that disease suppression towards potato scab was due to the activity of not pathogenic Streptomyces strains [113]. Since the early studies, the effective transfer of specific suppressiveness by soil inoculum has been demonstrated for many pathosystems, including the fungus Gaeumannomyces graminis var tritici, causing takeall of wheat [114], Rhizoctonia solani, which attacks sugar-beet and other vegetables [115], several forma specialis of Fusarium oxysporum [116], oomycetes belonging to Phytophthora and Pythium genus [117], bacteria like Ralstonia solanacearum [118], and some nematodes such as Meloidogyne incognita [119] and Heterodera spp. [120]. Although specific suppression transfer is a well-known method, it has not become an established agronomic practice yet. A major limitation is, obviously, the need to transfer $10 \%$ of the suppressive soil into the new agroecosystem, which appears to be an unrealistic task. However, soil transplantation could also be effective when using only $1 \%$ of donor soil, equivalent to $\sim 30 \mathrm{tha}^{-1}$ of soil, if assuming the amendment of a soil profile of $\sim 25 \mathrm{~cm}$ with a bulk density of $1.2 \mathrm{~g} \mathrm{~cm}^{-3}$. A recent study demonstrated that soil transplantation is possible at the field scale for rapid restoration of ex-arable land into semi-natural grasslands [121]. Under this scenario, soil transplantation appears to be a feasible practice, because $\sim 30 \mathrm{t} \mathrm{ha}^{-1}$ falls well within the range of organic amendment applications that are routinely made using manure, compost, and biochar [18]. Moreover, soil quantity does not appear to be a real constraint in the case of nursery or flower cultivations in greenhouses, where small amounts of substrates are used.

This body of evidence suggests that soil transplant could be a powerful tool for the development of sustainable agroecosystems. However, because of the very limited knowledge concerning the traits of donor soil microbiota and their compatibility with recipient soils, no reliable guidelines are currently available for farmers. Moreover, future studies would need to investigate the impact of soil transplant on the diversity and functionality of recipient microbiota. The enormous diversity of soils in terms of chemistry, together with the large variety of potentially useful donor microbiota define a great number of possible donor-recipient soils. Nowadays, no standardized approach is actually available for the identification of donors for the purposes of microbiota soil transplant, unlike what has been developed for the gut and vagina [110,122]. In this context, the aim for future work will be the development of a standardized process for donor screening, as well as rapid tests to assess the compatibility with the recipient soil, with the aim of optimizing crop performance.

\section{Conclusions and Future Directions}

This review highlights the deleterious effect of reiterated application of antibiotics in the gut and fumigations in soil. Such treatments, essential in some cases to control specific diseases, if applied routinely, disrupt the complex microbiota structure, causing a drop in their functionality that causes a reappraisal of infectious diseases. In this regard, the effectiveness of microbiota transplantation for managing gut diseases suggests new opportunities for the restoration of suppressive conditions in soils for controlling plant diseases. Ecosystems subject to periodical disturbance like antibiotics and soil sterilization become prone to biological invasion because their capability to efficiently use available resources is drastically reduced. Under this scenario, a drastic reduction of fumigants in agroecosystems appears to be of paramount importance in the development of suppressive soils. Removal of soil fumigation as a standard agronomic practice is also required for the rational and effective use of probiotics and organic amendment. In fact, well-characterized organic amendments can potentially be considered as a powerful tool for stirring suppressive microbiota, but several challenges still limit their extensive application. In this context, the comparison between soil and mammal gut identified key similarities among such complex systems. In both cases, organic input dominated by easily accessible carbon sources triggers microbiota dysbiosis and alteration of stable functionality. Further studies are required to better understand this functional convergence, especially taking into account 
that the different processes are operative in both the gut and soil. From an applicative point of view, future studies must pursue the correct balance in organic input in terms of CHO-MAC for dietary patterns. For soil, a reduction of the ratio between labile carbon sources and more refractory carbon input (i.e., cellulose, lignin, and pyrogenic organic carbon) seems to be a promising strategy, but more studies are needed to define specific guidelines applicable in different cultivation systems. More generally, this approach could open the way for the management of cellulose and lignin organic wastes in agriculture, thus supporting the sustainable use of resources in the context of the circular economy.

Author Contributions: Conceptualization, G.B.; investigation, G.B., M.I. and A.M.A.-E.; writingoriginal draft preparation, G.B.; writing-review and editing, G.B., M.I. and A.M.A.-E. All authors have read and agreed to the published version of the manuscript.

Funding: This research received no external funding.

Institutional Review Board Statement: Not applicable.

Informed Consent Statement: Not applicable.

Data Availability Statement: Not applicable.

Conflicts of Interest: The authors declare no conflict of interest.

\section{References}

1. Martin, F.N. Development of alternative strategies for management of soil-borne pathogens currently controlled with methyl bromide. Annu. Rev. Phytopathol. 2003, 41, 325-350. [CrossRef] [PubMed]

2. Huang, X.; Zhao, J.; Zhou, X.; Han, Y.; Zhang, J.; Cai, Z. How green alternatives to chemical pesticides are environmentally friendly and more efficient. Eur. J. Soil Sci. 2019, 70, 518-529. [CrossRef]

3. Tang, F.H.; Lenzen, M.; McBratney, A.; Maggi, F. Risk of pesticide pollution at the global scale. Nat. Geosci. 2021, 14, 206-210. [CrossRef]

4. Beckie, H.J.; Busi, R.; Lopez-Ruiz, F.J.; Umina, P.A. Herbicide resistance management strategies: How do they compare with those for insecticides, fungicides and antibiotics? Pest Manag. Sci. 2021, 77, 3049-3056. [CrossRef]

5. Storck, V.; Karpouzas, D.G.; Martin-Laurent, F. Towards a better pesticide policy for the European Union. Sci. Total Environ. 2017, 575, 1027-1033. [CrossRef] [PubMed]

6. Zolin, B.; Cassin, M.; Mannino, I. Food Security, Food Safety and Pesticides: China and the EU Compared; University Ca'Foscari of Venice, Dept. of Economics: Venezia, Italy, 2017; Volume 2. [CrossRef]

7. Agrios, G.N. Plant Pathology, 5th ed.; Elsevier Academia Press: San Diego, CA, USA, 2005.

8. Katan, J.; DeVay, J.E. Soil Solarization; CRC Press: Boca Raton, FL, USA, 1991.

9. Mazzola, M.; Hewavitharana, S.S.; Strauss, S.L. Brassica seed meal soil amendments transform the rhizosphere microbiome and improve apple production through resistance to pathogen reinfestation. Phytopathology 2014, 105, 460-469. [CrossRef] [PubMed]

10. Butler, D.M.; Kokalis-Burelle, N.; Albano, J.P.; McCollum, T.G.; Muramoto, J.; Shennan, C.; Rosskopf, E.N. Anaerobic soil disinfestation (ASD) combined with soil solarization as a methyl bromide alternative: Vegetable crop performance and soil nutrient dynamics. Plant Soil 2014, 378, 365-381. [CrossRef]

11. Diacono, M.; Montemurro, F. Long-term effects of organic amendments on soil fertility. Sustain. Agric. 2011, 2, 761-786.

12. Sarker, T.C.; Incerti, G.; Spaccini, R.; Piccolo, A.; Mazzoleni, S.; Bonanomi, G. Linking organic matter chemistry with soil aggregate stability: Insight from ${ }^{13} \mathrm{C}$ NMR spectroscopy. Soil Biol. Biochem. 2018, 117, 175-184. [CrossRef]

13. Hoitink HA, J.; Boehm, M.J. Biocontrol within the context of soil microbial communities: A substrate-dependent phenomenon. Annu. Rev. Phytopathol. 1999, 37, 427-446. [CrossRef]

14. Bonanomi, G.; Alioto, D.; Minutolo, M.; Marra, R.; Cesarano, G.; Vinale, F. Organic amendments modulate soil microbiota and reduce virus disease incidence in the TSWV-tomato pathosystem. Pathogens 2020, 9, 379. [CrossRef]

15. Lockwood, J.L. Biological control of soil-borne plant pathogens. In Relation of Energy Stress to Behaviour of Soil-Borne Plant Pathogens and to Disease Development; Hornby, D., Ed.; CAB International: Wallingford, UK, 1990; pp. 197-214.

16. Harman, G.E.; Howell, C.R.; Viterbo, A.; Chet, I.; Lorito, M. Trichoderma species-Opportunistic, avirulent plant symbionts. Nat. Rev. Microbiol. 2004, 2, 43-56. [CrossRef] [PubMed]

17. Blok, W.J.; Lamers, J.G.; Termorshuizen, A.J.; Bollen, G.J. Control of soilborne plant pathogens by incorporating fresh organic amendments followed by tarping. Phytopathology 2000, 90, 253-259. [CrossRef] [PubMed]

18. Bonanomi, G.; Antignani, V.; Pane, C.; Scala, F. Suppression of soilborne fungal diseases with organic amendments. J. Plant Pathol. 2007, 89, 311-324.

19. Scheuerell, S.; Mahaffee, W. Compost tea: Principles and prospects for plant disease control. Compost Sci. Util. 2002, 10, 313-338. [CrossRef] 
20. Elad, Y.; Cytryn, E.; Harel, Y.M.; Lew, B.; Graber, E.R. The biochar effect: Plant resistance to biotic stresses. Phytopathol. Mediterr. 2012, 50, 335-349.

21. Bonanomi, G.; Cesarano, G.; Antignani, V.; Di Maio, C.; De Filippis, F.; Scala, F. Conventional farming impairs Rhizoctonia solani disease suppression by disrupting soil food web. J. Phytopathol. 2018, 166, 663-673. [CrossRef]

22. De Corato, U. Disease-suppressive compost enhances natural soil suppressiveness against soil-borne plant pathogens: A critical review. Rhizosphere 2020, 13. [CrossRef]

23. Berendsen, R.L.; Pieterse, C.M.; Bakker, P.A. The rhizosphere microbiome and plant health. Trends Plant Sci. 2012, 17, 478-486. [CrossRef]

24. Pineda, A.; Kaplan, I.; Bezemer, T.M. Steering soil microbiomes to suppress aboveground insect pests. Trends Plant Sci. 2017, 22, 770-778. [CrossRef]

25. Modi, S.R.; Collins, J.J.; Relman, D.A. Antibiotics and the gut microbiota. J. Clin. Investig. 2014, 124, 4212-4218. [CrossRef]

26. Croswell, A.; Amir, E.; Teggatz, P.; Barman, M.; Salzman, N.H. Prolonged impact of antibiotics on intestinal microbial ecology and susceptibility to enteric Salmonella infection. Infect. Immun. 2009, 77, 2741-2753. [CrossRef]

27. Sharma, S.; Tripathi, P. Gut microbiome and type 2 diabetes: Where we are and where to go? J. Nutr. Biochem. 2019, 63, 101-108. [CrossRef] [PubMed]

28. Looft, T.; Allen, H.K. Collateral effects of antibiotics on mammalian gut microbiomes. Gut Microbes 2012, 3, 463-467. [CrossRef]

29. Alavi, S.; Mitchell, J.D.; Cho, J.Y.; Liu, R.; Macbeth, J.C.; Hsiao, A. Interpersonal gut microbiome variation drives susceptibility and resistance to cholera infection. Cell 2020, 181, 1533-1546. [CrossRef] [PubMed]

30. Ng, K.M.; Ferreyra, J.A.; Higginbottom, S.K.; Lynch, J.B.; Kashyap, P.C.; Gopinath, S.; Naidu, N.; Choudhury, B.; Weimer, B.C.; Monack, D.M.; et al. Microbiota-liberated host sugars facilitate post-antibiotic expansion of enteric pathogens. Nature 2013, 502, 96-99. [CrossRef] [PubMed]

31. Lange, K.; Buerger, M.; Stallmach, A.; Bruns, T. Effects of antibiotics on gut microbiota. Dig. Dis. 2016, 34, 260-268. [CrossRef] [PubMed]

32. Khoruts, A.; Sadowsky, M.J. Understanding the mechanisms of faecal microbiota transplantation. Nat. Rev. Gastroenterol. Hepatol. 2016, 13, 508-516. [CrossRef] [PubMed]

33. Fuentes, S.; Van Nood, E.; Tims, S.; Heikamp-de Jong, I.; Ter Braak, C.J.; Keller, J.J.; Zoetendal, E.G.; De Vos, W.M. Reset of a critically disturbed microbial ecosystem: Faecal transplant in recurrent Clostridium difficile infection. ISME J. 2014, 8, 1621-1633. [CrossRef] [PubMed]

34. Li, K.; DiLegge, M.J.; Minas, I.S.; Hamm, A.; Manter, D.; Vivanco, J.M. Soil sterilization leads to re-colonization of a healthier rhizosphere microbiome. Rhizosphere 2019, 12. [CrossRef]

35. Holmes, G.J.; Mansouripour, S.M.; Hewavitharana, S.S. Strawberries at the Crossroads: Management of soilborne diseases in California without methyl bromide. Phytopathology 2020, 110, 956-968. [CrossRef] [PubMed]

36. Bonanomi, G.; D’Ascoli, R.; Antignani, V.; Capodilupo, M.; Cozzolino, L.; Marzaioli, R.; Puopolo, G.; Rutigliano, F.A.; Scelza, R.; Scotti, R.; et al. Assessing soil quality under intensive cultivation and tree orchards in Southern Italy. Appl. Soil Ecol. 2011, 47, 184-194. [CrossRef]

37. Xue, C.; Shen, Z.; Hao, Y.; Yu, S.; Li, Y.; Huang, W.; Chong, Y.; Ran, W.; Li, R.; Shen, Q. Fumigation coupled with bio-organic fertilizer for the suppression of watermelon Fusarium wilt disease re-shapes the soil microbiome. Appl. Soil Ecol. 2019, 140, 49-56. [CrossRef]

38. Shen, Z.; Xue, C.; Penton, C.R.; Thomashow, L.S.; Zhang, N.; Wang, B.; Ruan, Y.; Li, R.; Shen, Q. Suppression of banana Panama disease induced by soil microbiome reconstruction through an integrated agricultural strategy. Soil Biol. Biochem. 2019, 128, 164-174. [CrossRef]

39. Smith, K.; McCoy, K.D.; Macpherson, A.J. Use of axenic animals in studying the adaptation of mammals to their commensal intestinal microbiota. In Seminars in Immunology; Academic Press: Cambridge, MA, USA, 2007; Volume 19, pp. 59-69.

40. Ge, A.H.; Liang, Z.H.; Xiao, J.L.; Zhang, Y.; Zeng, Q.; Xiong, C.; Han, L.; Wang, J.; Zhang, L.M. Microbial assembly and association network in watermelon rhizosphere after soil fumigation for Fusarium wilt control. Agric. Ecosyst. Environ. 2021, 312. [CrossRef]

41. Genoni, A.; Christophersen, C.T.; Lo, J.; Coghlan, M.; Boyce, M.C.; Bird, A.R.; Lyons-Wall, P.; Devine, A. Long-term Paleolithic diet is associated with lower resistant starch intake, different gut microbiota composition and increased serum TMAO concentrations. Eur. J. Nutr. 2020, 59, 1845-1858. [CrossRef]

42. Zhu, J.; Ren, Z.; Huang, B.; Cao, A.; Wang, Q.; Yan, D.; Ouyang, C.; Wu, J.; Li, Y. Effects of fumigation with allyl isothiocyanate on soil microbial diversity and community structure of tomato. J. Agric. Food Chem. 2020, 68, 1226-1236. [CrossRef] [PubMed]

43. Bonanomi, G.; De Filippis, F.; Zotti, M.; Idbella, M.; Cesarano, G.; Al-Rowaily, S.; Abd-ElGawad, A. Repeated applications of organic amendments promote beneficial microbiota, improve soil fertility and increase crop yield. Appl. Soil Ecol. $2020,156$. [CrossRef]

44. Bonanomi, G.; De Filippis, F.; Cesarano, G.; La Storia, A.; Ercolini, D.; Scala, F. Organic farming induces changes in soil microbiota that affect agro-ecosystem functions. Soil Biol. Biochem. 2016, 103, 327-336. [CrossRef]

45. Bonanomi, G.; Lorito, M.; Vinale, F.; Woo, S.L. Organic amendments, beneficial microbes, and soil microbiota: Toward a unified framework for disease suppression. Annu. Rev. Phytopathol. 2018, 56, 1-20. [CrossRef]

46. Davis, M.A.; Grime, J.P.; Thompson, K. Fluctuating resources in plant communities: A general theory of invasibility. J. Ecol. 2000, 88, 528-534. [CrossRef] 
47. Mendes, R.; Raaijmakers, J.M. Cross-kingdom similarities in microbiome functions. ISME J. 2015, 9, 1905-1907. [CrossRef] [PubMed]

48. Cartenì, F.; Sarker, T.C.; Bonanomi, G.; Cesarano, G.; Esposito, A.; Incerti, G.; Mazzoleni, S.; Lanzotti, V.; Giannino, F. Linking plant phytochemistry to soil processes and functions: The usefulness of ${ }^{13} \mathrm{C}$ NMR spectroscopy. Phytochem. Rev. 2018, 17, 815-832. [CrossRef]

49. Bäumler, A.J.; Sperandio, V. Interactions between the microbiota and pathogenic bacteria in the gut. Nature 2016, 535, 85-93. [CrossRef] [PubMed]

50. John, G.K.; Mullin, G.E. The gut microbiome and obesity. Curr. Oncol. Rep. 2016, 18, 1-7. [CrossRef] [PubMed]

51. Tang, W.W.; Hazen, S.L. The gut microbiome and its role in cardiovascular diseases. Circulation 2017, 135, 1008-1010. [CrossRef]

52. David, L.A.; Maurice, C.F.; Carmody, R.N.; Gootenberg, D.B.; Button, J.E.; Wolfe, B.E.; Ling, A.V.; Devlin, A.S.; Varma, Y.; Fischbach, M.A.; et al. Diet rapidly and reproducibly alters the human gut microbiome. Nature 2014, 505, 559-563. [CrossRef]

53. Portune, K.J.; Benítez-Páez, A.; Del Pulgar EM, G.; Cerrudo, V.; Sanz, Y. Gut microbiota, diet, and obesity-related disorders-The good, the bad, and the future challenges. Mol. Nutr. Food Res. 2017, 61. [CrossRef] [PubMed]

54. Zhang, W.; Han, D.Y.; Dick, W.A.; Davis, K.R.; Hoitink HA, J. Compost and compost water extract-induced systemic acquired resistance in cucumber and Arabidopsis. Phytopathology 1998, 88, 450-455. [CrossRef] [PubMed]

55. Gentile, C.L.; Weir, T.L. The gut microbiota at the intersection of diet and human health. Science 2018, 362, 776-780. [CrossRef] [PubMed]

56. Kong, C.; Gao, R.; Yan, X.; Huang, L.; Qin, H. Probiotics improve gut microbiota dysbiosis in obese mice fed a high-fat or high-sucrose diet. Nutrition 2019, 60, 175-184. [CrossRef] [PubMed]

57. Sonnenburg, E.D.; Smits, S.A.; Tikhonov, M.; Higginbottom, S.K.; Wingreen, N.S.; Sonnenburg, J.L. Diet-induced extinctions in the gut microbiota compound over generations. Nature 2016, 529, 212-215. [CrossRef] [PubMed]

58. Hryckowian, A.J.; Van Treuren, W.; Smits, S.A.; Davis, N.M.; Gardner, J.O.; Bouley, D.M.; Sonnenburg, J.L. Microbiota-accessible carbohydrates suppress Clostridium difficile infection in a murine model. Nat. Microbiol. 2018, 3, 662-669. [CrossRef] [PubMed]

59. Desai, M.S.; Seekatz, A.M.; Koropatkin, N.M.; Kamada, N.; Hickey, C.A.; Wolter, M.; Pudlo, N.A.; Kitamoto, S.; Terrapon, N.; Muller, A.; et al. A dietary fiber-deprived gut microbiota degrades the colonic mucus barrier and enhances pathogen susceptibility. Cell 2016, 167, 1339-1353. [CrossRef] [PubMed]

60. De Vadder, F.; Kovatcheva-Datchary, P.; Goncalves, D.; Vinera, J.; Zitoun, C.; Duchampt, A.; Bäckhed, F.; Mithieux, G. Microbiotagenerated metabolites promote metabolic benefits via gut-brain neural circuits. Cell 2014, 156, 84-96. [CrossRef] [PubMed]

61. Wilson, B.; Whelan, K. Prebiotic inulin-type fructans and galacto-oligosaccharides: Definition, specificity, function, and application in gastrointestinal disorders. J. Gastroenterol. Hepatol. 2017, 32, 64-68. [CrossRef]

62. Cohen, S.A.; Gold, B.D.; Oliva, S.; Lewis, J.; Stallworth, A.; Koch, B.; Laura, E.; Mason, D. Clinical and mucosal improvement with specific carbohydrate diet in pediatric Crohn disease. J. Pediatric Gastroenterol. Nutr. 2014, 59, 516-521. [CrossRef]

63. Hättenschwiler, S.; Gasser, P. Soil animals alter plant litter diversity effects on decomposition. Proc. Natl. Acad. Sci. USA 2005, 102, 1519-1524. [CrossRef]

64. Osnas, J.L.; Lichstein, J.W.; Reich, P.B.; Pacala, S.W. Global leaf trait relationships: Mass, area, and the leaf economics spectrum. Science 2013, 340, 741-744. [CrossRef]

65. Bonanomi, G.; Zotti, M.; Cesarano, G.; Sarker, T.C.; Saulino, L.; Saracino, A.; Idbella, M.; Agrelli, D.; D'Ascoli, R.; Rita, A.; et al. Decomposition of woody debris in Mediterranean ecosystems: The role of wood chemical and anatomical traits. Plant Soil 2021, 460, 263-280. [CrossRef]

66. Knicker, H. How does fire affect the nature and stability of soil organic nitrogen and carbon? A review. Biogeochemistry 2007, 85, 91-118. [CrossRef]

67. Hardison, J.R. Fire and flame for plant disease control. Annu. Rev. Phytopathol. 1976, 14, 355-379. [CrossRef]

68. De Vries, F.T.; Bloem, J.; van Eekeren, N.; Brusaard, L.; Hoffland, E. Fungal biomass in pastures increases with age and reduced N input. Soil Biol. Biochem. 2007, 39, 1620-1630. [CrossRef]

69. Clocchiatti, A. Bringing Soil Fungi into Action: Options for Forward-Looking Agriculture; Wageningen University: Wageningen, The Netherlands, 2021.

70. Savory, B.M. Specific Replant Diseases; Commonwealth Agricultural Bureaux: Wallingford, UK, 1966.

71. Troelstra, S.R.; Wagenaar, R.; Smant, W.; Peters, B.A.M. Interpretation of bioassays in the study of interactions between soil organisms and plants: Involvement of nutrient factors. New Phytol. 2001, 150, 697-706. [CrossRef]

72. Cesarano, G.; Zotti, M.; Antignani, V.; Marra, R.; Scala, F.; Bonanomi, G. Soil sickness and negative plant-soil feedback: A reappraisal of hypotheses. J. Plant Pathol. 2017, 99, 545-570.

73. Moora, M.; Öpik, M.; Sen, R.; Zobel, M. Native arbuscular mycorrhizal fungal communities differentially influence the seedling performance of rare and common Pulsatilla species. Funct. Ecol. 2004, 18, 554-562. [CrossRef]

74. Bonanomi, G.; Mingo, A.; Incerti, G.; Mazzoleni, S.; Allegrezza, M. Fairy rings caused by a killer fungus foster plant diversity in species-rich grassland. J. Veg. Sci. 2012, 23, 236-248. [CrossRef]

75. He, M.; Tian, G.; Semenov, A.M.; Van Bruggen, A.H. Short-term fluctuations of sugar beet damping-off by Pythium ultimum in relation to changes in bacterial communities after organic amendments to two soils. Phytopathology 2012, 102, 413-420. [CrossRef] 
76. Van Bruggen, A.H.C.; Semenov, A.M.; van Diepeningen, A.D.; de Vos, O.J.; Blok, W.J. Relation between soil health, wave-like fluctuations in microbial populations, and soil-borne plant disease management. In Plant Disease Epidemiology: Facing Challenges of the 21st Century; Springer: Dordrecht, The Netherlands, 2006; pp. 105-122.

77. Dick, R.P.; Rasmussen, P.E.; Kerle, E.A. Influence of long-term residue management on soil enzyme activities in relation to soil chemical properties of a wheat-fallow system. Biol. Fertil. Soils 1988, 6, 159-164. [CrossRef]

78. Kandeler, E.; Stemmer, M.; Klimanek, E.M. Response of soil microbial biomass, urease and xylanase within particle size fractions to long-term soil management. Soil Biol. Biochem. 1999, 31, 261-273. [CrossRef]

79. Bonanomi, G.; Gaglione, S.A.; Cesarano, G.; Sarker, T.C.; Pascale, M.; Scala, F.; Zoina, A. Frequent applications of organic matter to agricultural soil increase fungistasis. Pedosphere 2017, 27, 86-95. [CrossRef]

80. Clocchiatti, A.; Hannula, S.E.; van den Berg, M.; Korthals, G.; De Boer, W. The hidden potential of saprotrophic fungi in arable soil: Patterns of short-term stimulation by organic amendments. Appl. Soil Ecol. 2020, 147. [CrossRef]

81. Hodge, A.; Robinson, D.; Fitter, A. Are microorganisms more effective than plants at competing for nitrogen? Trends Plant Sci. 2000, 5, 304-308. [CrossRef]

82. Eizenberg, H.; Plakhine, D.; Ziadne, H.; Tsechansky, L.; Graber, E.R. Non-chemical control of root parasitic weeds with biochar. Front. Plant Sci. 2017, 8, 939. [CrossRef] [PubMed]

83. George, C.; Kohler, J.; Rillig, M.C. Biochars reduce infection rates of the root-lesion nematode Pratylenchus penetrans and associated biomass loss in carrot. Soil Biol. Biochem. 2016, 95, 11-18. [CrossRef]

84. Postma, J.; Clematis, F.; Nijhuis, E.H.; Someus, E. Efficacy of four phosphate-mobilizing bacteria applied with an animal bone charcoal formulation in controlling Pythium aphanidermatum and Fusarium oxysporum $f$. sp. radicis lycopersici in tomato. Biol. Control 2013, 67, 284-291. [CrossRef]

85. Jaiswal, A.K.; Frenkel, O.; Tsechansky, L.; Elad, Y.; Graber, E.R. Immobilization and deactivation of pathogenic enzymes and toxic metabolites by biochar: A possible mechanism involved in soilborne disease suppression. Soil Biol. Biochem. 2018, 121, 59-66. [CrossRef]

86. Wolf, R.; Wedig, H. Process for Manufacturing a Soil Conditioner. U.S. Patent No WO 2,010,055,139 A1, 20 May 2010.

87. Bonanomi, G.; Ippolito, F.; Cesarano, G.; Nanni, B.; Lombardi, N.; Rita, A.; Saracino, A.; Scala, F. Biochar As Plant Growth Promoter: Better Off Alone or Mixed with Organic Amendments? Front. Plant Sci. 2017, 8, 1570. [CrossRef] [PubMed]

88. Hagemann, N.; Joseph, S.; Schmidt, H.P.; Kammann, C.I.; Harter, J.; Borch, T.; Young, R.B.; Varga, K.; Taherymoosavi, S.K.; Elliott, W.; et al. Organic coating on biochar explains its nutrient retention and stimulation of soil fertility. Nat. Commun. 2017, 8, 1-11. [CrossRef] [PubMed]

89. Lorito, M.; Woo, S.L.; Harman, G.E.; Monte, E. Translational research on Trichoderma: From'omics to the field. Annu. Rev. Phytopathol. 2010, 48, 395-417. [CrossRef]

90. Bardin, M.; Pugliese, M. Biocontrol agents against diseases. In Integrated Pest and Disease Management in Greenhouse Crops; Springer: Cham, Switzerland, 2020; pp. 385-407.

91. Ram, R.M.; Singh, H.B. Microbial consortium in biological control: An explicit example of teamwork below ground. J. Eco-Friendly Agric. 2018, 13, 1-12.

92. Zhang, F.; Luo, W.; Shi, Y.; Fan, Z.; Ji, G. Should we standardize the 1,700-year-old fecal microbiota transplantation? Am. J. Gastroenterol. 2012, 107, 1755. [CrossRef] [PubMed]

93. Mandal, R.S.K.; Joshi, V.; Balamurugan, B.; Gautam, D.; Chethan, G.E.; Lekshman, A. Rumen transfaunation an effective method for treating simple indigestion in ruminants. North-East Vet. 2017, 17, 31-33.

94. Stagaman, K.; Burns, A.R.; Guillemin, K.; Bohannan, B.J. The role of adaptive immunity as an ecological filter on the gut microbiota in zebrafish. ISME J. 2017, 11, 1630-1639. [CrossRef] [PubMed]

95. Eiseman, B.; Silen, W.; Bascom, G.S.; Kauvar, A.J. Fecal enema as an adjunct in the treatment of pseudomembranous enterocolitis. Surgery 1958, 44, 854-859. [PubMed]

96. Sbahi, H.; Di Palma, J.A. Faecal microbiota transplantation: Applications and limitations in treating gastrointestinal disorders. BMJ Open Gastroenterol. 2016, 3. [CrossRef] [PubMed]

97. Sunkara, T.; Rawla, P.; Ofosu, A.; Gaduputi, V. Fecal microbiota transplant-a new frontier in inflammatory bowel disease. J. Inflamm. Res. 2018, 11, 321. [CrossRef] [PubMed]

98. Vaughn, B.P.; Vatanen, T.; Allegretti, J.R.; Bai, A.; Xavier, R.J.; Korzenik, J.; Gevers, D.; Ting, A.; Robson, S.C.; Moss, A.C. Increased intestinal microbial diversity following fecal microbiota transplant for active Crohn's disease. Inflamm. Bowel Dis. 2016, 22, 2182-2190. [CrossRef]

99. Ding, X.; Li, Q.; Li, P.; Zhang, T.; Cui, B.; Ji, G.; Lu, X.; Zhang, F. Long-term safety and efficacy of fecal microbiota transplant in active ulcerative colitis. Drug Saf. 2019, 42, 869-880. [CrossRef]

100. Pinn, D.M.; Aroniadis, O.C.; Brandt, L.J. Is fecal microbiota transplantation (FMT) an effective treatment for patients with functional gastrointestinal disorders (FGID)? Neurogastroenterol. Motil. 2015, 27, 19-29. [CrossRef]

101. Marotz, C.A.; Zarrinpar, A. Focus: Microbiome: Treating obesity and metabolic syndrome with fecal microbiota transplantation. Yale J. Biol. Med. 2016, 89, 383.

102. Kootte, R.S.; Levin, E.; Salojärvi, J.; Smits, L.P.; Hartstra, A.V.; Udayappan, S.D.; Hermes, G.; Bouter, K.E.; Koopen, A.M.; Holst, J.J.; et al. Improvement of insulin sensitivity after lean donor feces in metabolic syndrome is driven by baseline intestinal microbiota composition. Cell Metab. 2017, 26, 611-619. [CrossRef] [PubMed] 
103. McQuade, J.L.; Ologun, G.O.; Arora, R.; Wargo, J.A. Gut microbiome modulation via fecal microbiota transplant to augment immunotherapy in patients with melanoma or other cancers. Curr. Oncol. Rep. 2020, 22, 1-9. [CrossRef] [PubMed]

104. Guo, W.; Ren, K.; Ning, R.; Li, C.; Zhang, H.; Li, D.; Xu, L.; Sun, F.; Dai, M. Fecal microbiota transplantation provides new insight into wildlife conservation. Glob. Ecol. Conserv. 2020, 24. [CrossRef]

105. Pereira, G.Q.; Gomes, L.A.; Santos, I.S.; Alfieri, A.F.; Weese, J.S.; Costa, M.C. Fecal microbiota transplantation in puppies with canine parvovirus infection. J. Vet. Intern. Med. 2018, 32, 707-711. [CrossRef]

106. Niederwerder, M.C.; Constance, L.A.; Rowland, R.R.R.; Abbas, W.; Fernando, S.C.; Potter, M.L.; Sheahan, M.A.; Burkey, T.E.; Hesse, R.A.; Cino-Ozuna, A.G. Fecal microbiota transplantation is associated with reduced morbidity and mortality in porcine circovirus associated disease. Front. Microbiol. 2018, 9, 1631. [CrossRef] [PubMed]

107. Lev-Sagie, A.; Goldman-Wohl, D.; Cohen, Y.; Dori-Bachash, M.; Leshem, A.; Mor, U.; Strahilevitz, J.; Moses, A.E.; Shapiro, H.; Yagel, S.; et al. Vaginal microbiome transplantation in women with intractable bacterial vaginosis. Nat. Med. 2019, 25, 1500-1504. [CrossRef] [PubMed]

108. Ravel, J.; Brotman, R.M. Translating the vaginal microbiome: Gaps and challenges. Genome Med. 2016, 8, 1-3. [CrossRef] [PubMed]

109. Peipert, J.F.; Montagno, A.B.; Cooper, A.S.; Sung, C.J. Bacterial vaginosis as a risk factor for upper genital tract infection. Am. J. Obstet. Gynecol. 1997, 177, 1184-1187. [CrossRef]

110. Bradshaw, C.S.; Morton, A.N.; Hocking, J.; Garland, S.M.; Morris, M.B.; Moss, L.M.; Horvath, L.B.; Kuzevska, I.; Fairley, C.K High recurrence rates of bacterial vaginosis over the course of 12 months after oral metronidazole therapy and factors associated with recurrence. J. Infect. Dis. 2006, 193, 1478-1486. [CrossRef]

111. Bohbot, J.M.; Daraï, E.; Bretelle, F.; Brami, G.; Daniel, C.; Cardot, J.M. Efficacy and safety of vaginally administered lyophilized Lactobacillus crispatus IP 174178 in the prevention of bacterial vaginosis recurrence. J. Gynecol. Obstet. Hum. Reprod. 2018, 47, 81-86. [CrossRef]

112. DeLong, K.; Bensouda, S.; Zulfiqar, F.; Zierden, H.C.; Hoang, T.M.; Abraham, A.G.; Coleman, J.S.; Cone, R.A.; Gravitt, P.E.; Hendrix, C.W.; et al. Conceptual design of a universal donor screening approach for vaginal microbiota transplant. Front. Cell. Infect. Microbiol. 2019, 9, 306. [CrossRef]

113. Weller, D.M.; Raaijmakers, J.M.; Gardener BB, M.; Thomashow, L.S. Microbial populations responsible for specific soil suppressiveness to plant pathogens. Annu. Rev. Phytopathol. 2002, 40, 309-348. [CrossRef]

114. Menzies, J. Occurrence and transfer of a biological factor in soil that suppresses potato scab. Phytopathology 1959, 49, 648-652.

115. Liu, D.; Anderson, N.A.; Kinkel, L.L. Biological control of potato scab in the field with antagonistic Streptomyces scabies. Phytopathology 1995, 85, 827-831. [CrossRef]

116. Cook, R.J.; Rovira, A.D. The role of bacteria in the biological control of Gaeumannomyces graminis by suppressive soils. Soil Biol. Biochem. 1976, 8, 269-273. [CrossRef]

117. Mendes, R.; Kruijt, M.; De Bruijn, I.; Dekkers, E.; van der Voort, M.; Schneider, J.H.; Piceno, Y.M.; DeSantis, T.Z.; Andersen, G.L.; Bakker, P.A.H.M.; et al. Deciphering the rhizosphere microbiome for disease-suppressive bacteria. Science 2011, 332, 1097-1100. [CrossRef] [PubMed]

118. Alabouvette, C. Fusarium wilt suppressive soils: An example of disease-suppressive soils. Australas. Plant Pathol. 1999, 28 , 57-64. [CrossRef]

119. Martin, F.N.; Hancock, J.G. Association of chemical and biological factors in soils suppressive to Pythium ultimum. Phytopathology 1986, 76, 1221-1231. [CrossRef]

120. Nishiyama, M.; Shiomi, Y.; Suzuki, S.; Marumoto, T. Suppression of growth of Ralstonia solanacearum, tomato bacterial wilt agent, on/in tomato seedlings cultivated in a suppressive soil. Soil Sci. Plant Nutr. 1999, 45, 79-87. [CrossRef]

121. Pyrowolakis, A.; Westphal, A.; Sikora, R.A.; Beckerb, J.O. Identification of root-knot nematode suppressive soils. Appl. Soil Ecol. 2002, 19, 51-56. [CrossRef]

122. Song, J.; Li, S.; Xu, Y.; Wei, W.; Yao, Q.; Panet, F. Diversity of parasitic fungi from soybean cyst nematode associated with long-term continuous cropping of soybean in black soil. Acta Agric. Scand. B Soil Plant Sci. 2016, 66, 432-442. [CrossRef] 